\title{
Microbial inoculum development for ameliorating crop drought stress: a case study of Variovorax paradoxus 5C-2
}

Rosalia Garcia Teijeiro. ${ }^{1,3, *}$; Andrey A. Belimov. ${ }^{2}$; Ian C. Dodd. ${ }^{1, *}$

${ }^{1}$ The Lancaster Environment Centre, Lancaster University, Lancaster, LA1 4YQ, UK, email: I.dodd@lancaster.ac.uk

${ }^{2}$ All-Russia Research Institute for Agricultural Microbiology, Podbelskogo Sh. 3, Pushkin-8, 196608, Saint Petersburg, Russian Federation

${ }^{3}$ University of Natural Resources and Life Sciences, University Research Center, 3430 Tulln an der Donau, Austria. r.g.teijeiro@gmail.com

* Corresponding Author

Abbreviations

PGPR: plant growth promoting rhizobacteria

ABA: abscisic acid

ACC: aminocyclopropane-1-carboxylate

acdS: aminocyclopropane-1-carboxylate deaminase

QS: quorum sensing

AHL: acyl homoserine lactone

\section{Keywords:}

ACC deaminase; ethylene, pan-genome, rhizosphere colonisation, Variovorax paradoxus, sustainable agriculture, climate change

\footnotetext{
Abstract

Drought affects plant hormonal homeostasis, including root to shoot signalling. The plant is intimately connected below-ground with soil-dwelling microbes, including plant growth promoting rhizobacteria (PGPR) that can modulate plant hormonal homeostasis. Incorporating PGPR into the rhizosphere often delivers favourable results in greenhouse experiments, while field applications are much less predictable. We review the natural processes that affect the formation and dynamics of the rhizosphere, establishing a model for successful field application of PGPR utilizing an example microbial inoculum, Variovorax paradoxus 5C-2.
} 


\section{Introduction}

The world faces a major water crisis as a consequence of unsustainable human water withdrawal (primarily for irrigation) and alterations in natural hydrological cycles through agriculture, industrial and urban activities $[1,2]$. Climate change will stimulate additional water demands in many agricultural regions [3]. The need to increase food production by at least $50 \%$ to feed an increasing population with greater wealth and food demands, could create feedbacks increasing the loss of freshwater quantity and quality [4]. Consequently, changes in agricultural practices are needed, based on multi-disciplinary scientific research and working in cooperation with farmers and policy-makers.

Knowledge from basic and applied sciences can be employed to fulfil the needs of modern producers. Although classical plant breeding methods have seen extensive application culminating in the development of more drought-tolerant crops, both ethical and practical limitations have constrained the development of genetically modified (GM) drought-resistant crops [5]. Specifically, drought tolerance is usually regulated by finely synchronized multi-gene systems that are difficult to manipulate [6]. Moreover, logistical difficulties occur in producing GM crops when considering variations of drought tolerant genes networks between different species, or even among different cultivars $[6,7,8]$.

Another biotechnological option has been to use soil-dwelling microbes that interact with plant root systems, namely plant growth promoting rhizobacteria (PGPR) [9], which dwell on, and sometimes in, plant roots and confer stress tolerance via multiple mechanisms [10,11]. This review is focused on utilising PGPR to enhance crop fitness under drought conditions, especially since they are more effective in promoting growth and crop yields under drought conditions. By presenting a case study of the development of an exemplar PGPR, namely Variovorax paradoxus 5C-2, as a microbial inoculum, key concepts are introduced to help match an agricultural scenario with successful PGPR activity.

Plants adapt to changing soil water availability by "measuring" soil water status $[12,13]$. When the soil water status is low enough (below $-0.05 \mathrm{MPa}$ ), root metabolism changes. Transcriptomics data [14] and headspace analysis [15] indicate that plants respond to abiotic stresses by producing the volatile plant hormone ethylene, which is aerially transported from one 
plant to another plant within a community. Elevated ethylene biosynthesis decreases yield by inhibiting growth, photosynthesis and seed set [16]. Although ethylene promotes fruit ripening, it accelerates leaf senescence and inhibits leaf growth. Ethylene also induces lateral cell expansion in stems and roots. In addition, ethylene increases root hair density and length [17], but inhibits primary root growth [18]. Ethylene-mediated growth inhibition has made the genetic, chemical or microbial manipulation of ethylene levels in planta an attractive biotechnological target.

\section{ACC as a key inter-kingdom signal molecule}

In terrestrial plants, ethylene biosynthesis involves the methionine metabolic pathway (Figure 1) [14]. In this process, the conversion of 1-aminocyclopropane-1-carboxylate (ACC) to ethylene is regarded as a rate-limiting step. Moreover, ACC can also be bound with organic compounds to produce malonyl-ACC (M-ACC), $\gamma$-glutamyl-ACC (G-ACC) and jasmonoyl-ACC (JA-ACC). Additionally, ACC can be transformed by plant [19] and microbial enzymes known as 1-aminocyclopropane-1-carboxylate deaminases (ACC deaminase, gene notation acdS) into 2oxobutanoate and ammonia. Hence, ACC is a central biochemical player in integrating plant and microbial (inter-kingdom) metabolic networks and its root to shoot signalling is an important component of plant adaptation to drought [20].

Although the root system is regarded as the primary sensor of soil conditions, microorganisms inhabiting the surface of, or inside, the root can influence root-to-shoot signalling processes $[9,10,11]$. Indeed, some PGPR producing ACC deaminase modulate root ACC levels and hence root [11] and shoot [21] ethylene evolution. When plants grown in drying soil were exposed to bacterial ACC deaminase, they developed a longer root system and had increased biomass and yield [22] suggesting this plant-microbe interaction is of adaptive significance in increasing plant drought tolerance. Interestingly, wild barley (Hordeum spontaneum) plants exposed to more stressful environments in natural settings have a higher proportion of ACCd-containing rhizobacteria on their root systems [23]. Moreover, withholding irrigation from wheat (Triticum aestivum) plants increased the relative abundance of acdscontaining rhizobacteria on the root system [24]. Understanding how plants regulate the recruitment of such PGPR represents a potential biotechnological opportunity to enhance plant drought tolerance. 
Agricultural practices and climate warming decrease soil biodiversity, community composition and activity, affecting the delivery of ecosystem services $[25,26]$. The important meaning of richness and diversity in a given soil community lies in the number of species that undertake specific ecosystem services such as inducing plant drought fitness. The rhizosphere can be defined as the soil adjacent to the root systems that is biologically, chemically and physically influenced by the root system, distinct from the remaining bulk soil that is not $[27,28]$. The rhizosphere is enriched, both in numbers and in the proportion of certain taxa, with certain soil microbes compared to the bulk soil "starting" community composition. Evidence based on qPCR of all $a c d \mathrm{~S}$ alleles and Illumina sequencing of $a c d \mathrm{~S}$ from DNA of rhizosphere of different Poaceae species (including maize) shows that contrasting plant genotypes preferentially recruit acdS alleles from the bulk soil [29, 24]. When microbial biodiversity is impaired, plant selection of different acdS alleles may be compromised. Efforts to understand the regulation of rhizosphere microbial dynamics is fundamental for the compatible application of PGPR to drought-stressed crops.

\section{Characteristics and dynamics of the plant holobiont}

Each plant species and its habitat have a unique consortium of microbes, the microbiota $[30,31]$. Altogether the microbiota's genetic information is referred as the microbiome, and the concurrence of the host organism with the microbiota is the "holobiont". Although each organism presents its own independent mechanism of survival, their co-evolution coordinates their metabolic processes resulting in increased fitness of the holobiont. Moreover, the holobiont possesses its "hologenome": the aggregate of microbiome and host genomes. Such integration of genetic material from diverse organisms results in the formation of superorganism genetic systems. Therefore, altering the composition of the holobiont may potentially affect interkingdom signalling thereby changing fitness/growth of the host [30].

High throughput sequencing surveys of many rhizospheric microbiota show consistent repetition (at phylum level) between different plant species. Bacteria encompass $90 \%$ of the holobiome and the dominant phyla are the Proteobacteria, followed by Actinobacteria, Bacteroidetes, Firmicutes, Verrucomicrobia, and Acidobacteria [11]. Nevertheless, different bacterial species occur even between different plant cultivars growing in the same soil [32]. 
Bacterial population dynamics (species composition and number) are strongly influenced by their environment, such as soil water availability. Soils affected by drought events tend to be enriched with bacteria that tolerate desiccation. The spore-forming phyla Actinobacteria and Firmicutes are described as drought-resistant [33], even though several members of the Actinobacteria are drought-sensitive [34]. While the Verrucomicrobia are regarded as droughttolerant, they have not yet been described as having ACC deaminase activity. Thus while there is no absolute association of ACC deaminase and bacterial drought-tolerance, drought-stressed plants tend to select for the occurrence of $a c d S$ alleles in their rhizosphere [29, 24]. Consequently, there has been much interest in isolating and culturing free-living PGPR containing the ACC deaminase gene [11]. When developing microbial inocula for agriculture, it is crucial to understand the factors influencing PGPR activity in agricultural ecosystems to mitigate plant drought stress responses.

\section{Challenges of using PGPR to alter hormonal dynamics in planta}

Soil inoculation with PGPR to promote crop yields has delivered some promising results. Furthermore, these techniques are environmentally friendly, since inoculant impacts on rhizospheric community dynamics are either positive, i.e. cooperative or synergistic, or null [35]. Applying PGPR has generally been accepted by farmers, since there has been a long history of using rhizobacterial inoculants, with the first patent granted in the USA in 1896 for inoculating leguminous field crops with nitrogen-fixing Rhizobium spp [36, 11]. The first non-symbiotic microorganism (Azospirillum) to promote plant growth was commercially released in 1981 [36]. However, most PGPR products are marketed as bio-control (70\%) and bio-fertilizers (25\%), with only $5 \%$ formulated to enhance plant stress tolerance [36]. Nevertheless, PGPR inoculation sometimes fails under field conditions, often due to diminished fitness of the inoculum in competing with native microbial communities [37, 38]. Successful inoculation of the soil requires that it supplies the minimum bacterial physiological requirements to grow and colonize the appropriate niche: the rhizosphere, rhizoplane or plant root cells.

Three major environmental components drive the holobiont assemblage in agricultural plant hosts. Firstly, soils determine both physical and chemical characteristics of environmental 
niches for bacteria, via variation in structure, porosity, texture, nutrients, and $\mathrm{pH}[39,40]$. Secondly, plant genotype governs the quantity and quality of nutrients and chemicals signals accessible to the microorganism. Finally, agricultural practices/field history (e.g. application of herbicides and soil amendments such as lime, manure and microbial inoculants) will affect microbial populations and community diversity [40].

To demonstrate how these environmental components affect the success of microbial inoculation, an example PGPR bacterium, Variovorax paradoxus, is used. This species shows valuable traits such as osmotic stress resistance, resistance to some biocidal compounds applied in agriculture and high competitiveness [41, 42, 43], which will be advantageous when it is applied to a field in which there is limited information concerning its management history.

The genetic diversity of $V$. paradoxus was probed by studying the total collection of genes within the genomes of seven $V$. paradoxus strains, the pan-genome [44], containing an average of 6000 genes (Table 1). The pan-genome of $V$. paradoxus strains shares 3400 genes in common, the core genome, but also has an average of 2000 genes shared by some strains, the variable or accessory genome, and an average of 65 unique genes for each strain [45]. The percentage of genes covering functions in metabolism of amino acids, carbohydrates, lipids, xenobiotic biodegradation and motility are shared by both core, variable and unique pan-genome (Figure 2). Thus pan-genomes and core genomes of $V$. paradoxus strains are functionally linked to the metabolic versatility and plant growth promotion traits. In particular, multi-drug resistance features present in $V$. paradoxus confer pesticide-antibiotic cross-resistance, implying the organism can adapt to different environmental constraints $[42,46]$.

V. paradoxus 5C-2 was first isolated from the roots of Brassica juncea L. Czern plants growing in soils contaminated with cadmium, based on its growth of ACC as a sole nitrogen source [43]. It is a facultative oligotrophic, Gram negative bacterium that can grow in both nutrient-poor and nutrient-rich media. To compete, endure and settle in the rhizosphere, $V$. paradoxus 5C-2 displays quorum sensing (QS). In addition, V. paradoxus 5C-2 may shape the bacterial population around the root as it can also degrade QS signals and utilize AHLs as a carbon source (A.A. Belimov, unpublished data). The N-Acyl homoserine lactone lactonase (AIIA) activity of $V$. paradoxus provides "quorum quenching", allowing the bacteria to degrade 
and grow on acyl-HSL signals [43]. $V$. paradoxus 5C-2 has multiple PGPR features including the synthesis of indole-3-acetic acid (IAA), the expression of ACC deaminase activity [43] and enhancing nutrient uptake and partitioning in planta [47].

Successfully applying $V$. paradoxus $5 \mathrm{C}-2$ as a soil inoculant will depend on its adaptive capacity to new, potentially hostile soil conditions, e.g. temperature, $\mathrm{pH}$ and water content, and competition with native organisms [48]. Ultimately, the physiological needs of the inoculum must match those it will encounter in the new environment.

\section{Soil temperature}

Soil temperature is one of the most important factors affecting the dynamics of the rhizosphere $[49,50]$. Microbial activity rate doubles for every $10^{\circ} \mathrm{C}$ rise in temperature until a point, depending on the temperature sensitivity of the microorganism, when high temperatures disrupt enzyme structure and cellular material. Moreover, temperature changes the physical properties of the environment such as surface adhesivity, thus affecting microbial motility [49]. Soil temperature depends on the irradiation energy, soil reflectivity (albedo), rainfall and topology, and increases during drought events when surface evaporation is decreased by low soil water content [51]. Soil temperature decreases with depth, which may influence the inoculation technique used in arid environments.

$V$. paradoxus $5 \mathrm{C}-2$ is a mesophile microorganism, with optimal growth at $28^{\circ} \mathrm{C}$ (Figure 3A). However, maximum motility was measured at $30^{\circ} \mathrm{C}$, with no measurable motility at temperatures less than or equal to $15^{\circ} \mathrm{C}$, or more than or equal to $37^{\circ} \mathrm{C}$ (Figure $3 \mathrm{~A}$ ). This information helps determine the correct ecosystem climate zone and time of the year to apply this bacterium to encourage its proliferation [52]. It will proliferate when spring-summer minimum soil temperatures average $18^{\circ} \mathrm{C}$, but local agricultural practices that trigger temperatures above $28^{\circ} \mathrm{C}$ should be avoided. In crops grown in black plastic mulch to minimise weed growth, surface soil temperature can exceed $28^{\circ} \mathrm{C}$ [53], thus $V$. paradoxus $5 \mathrm{C}-2$ inoculation may be ineffective when plants are mulched.

In agro-ecosystems from lower latitudes, drought events combined with high air temperatures trigger surface soil temperatures higher than $40^{\circ} \mathrm{C}$ in more than half the soils in 
Europe [49]. In this scenario, thermophile PGPRs may be better able to establish following inoculation, depending on the method of inoculation. Since most of the PGPRs currently isolated are mesophile, there is increasing interest in isolating themophilic PGPRs from desert environments [54]. $V$. paradoxus isolation from such environments suggests that it manages to find a temperature niche that allows its proliferation.

\section{Soil pH}

In agricultural soils, $\mathrm{pH}$ determines the availability of nutrients and metals, affecting microbial composition and biomass [55]. Bacterial species exhibit various tolerances to $\mathrm{pH}$, with most growing in a $\mathrm{pH}$ range between 6 and 9, but generally growing best at neutral conditions [48]. $\mathrm{pH}$ effects on bacterial motility and fitness will mediate the rhizosphere bacterial community. Alkaline $\mathrm{pH}(>8.5)$ suppresses bacterial motility [56], while catabolic reactions that consume acids are favoured at acidic $\mathrm{pH}(<6.5)$. Alkaline $\mathrm{pH}$ represses chemotaxis systems, perhaps due to their energetic cost [57].

Of those $\mathrm{pHs}$ tested, minimal growth of $V$. paradoxus $5 \mathrm{C}-2$ occurred at $\mathrm{pH} 4$ and $\mathrm{pH} 9$ (Figure 3.B). V. paradoxus 5C-2 g with growth and motility maximal between 5 and 7(Figure 3.B). It resisted acidic $\mathrm{pHs}$, because the growth and motility curve was high between $\mathrm{pH} 5$ and 8 and skewed towards an acidic range (Figure 3.B). This optimal $\mathrm{pH}$ embraces the range recommended by agronomists ( $\mathrm{pH} \mathrm{6-7)}$ ) for good crop nutrition. Nevertheless, highly leached tropical soils are often acidic, which mobilises aluminium in the soil solution which can be toxic for plant growth and inhibits root elongation [58]. Since ethylene is involved in root growth inhibition under aluminum toxicity, the possibility that $a c d S$-containing rhizobacteria such as $V$. paradoxus 5C-2 can overcome Al-mediated root growth inhibition [59] merits further research.

\section{Soil water availability}

Bacteria maintain a certain cellular water content for optimal metabolism and soil water availability is perhaps one of the most influential factors that shape a microbial community [50]. Drought destabilises the bacterial community network, changing the trophic network dynamics [34]. The community tends to reorganize their populations towards drought tolerant bacteria (phylum Verrucomicrobia and the class Alphaproteobacteria). The bacterial semipermeable outer 
membrane allows rapid equilibration of cellular contents with soil water, consequently soil drying, which decreases water potential, decreases bacterial internal water potential. Bacterial accumulation of solutes, or osmolytes, is one survival strategy to maintain a favourable water potential gradient, but leaves the bacteria riskily dependent on nutrient availability [60]. Drought-induced morbidity can result from damage to the outer cell membrane, which may explain the higher resistance of Gram positive bacteria to desiccation. This effect varies between species and should be determined for each bacterium [61].

Since $V$. paradoxus 5C-2 lives naturally in the rhizosphere, it can be exposed to a wide range of water potentials, which may be as low as $-10 \mathrm{MPa}$ [62]. To simulate the effects of soil drying on bacteria, glycerol was added to TSB medium to impose a range of osmotic potentials $(-0.14$ to $-12 \mathrm{MPa})$. There was no significant effect on $V$. paradoxus 5C-2 survival but the bacteria were not motile (Figure 3.C). Indeed, motility steadily decreased from $-0.17 \mathrm{MPa}$ to $0.24 \mathrm{MPa}$ and bacteria were immobile below -0.54 MPa. After cells were exposed to different osmotic potentials in liquid media for 12 hours, motility tests were conducted to study whether $V$. paradoxus 5C-2 survives at low osmotic potential but loses its ability to resume motility (Figure 3D). Exposure to even the lowest osmotic potential tested (-12 MPa) did not diminish subsequent V. paradoxus 5C-2 motility.

Compared to some other bacteria, $V$. paradoxus $5 \mathrm{C}-2$ seems more resistant to osmotic shocks. In Rhizobium sp., the growth is minimal at $-5 \mathrm{MPa}$ [63] while this osmotic stress had no effect in $V$. paradoxus 5C-2. Lower osmotic tolerance of $R$. leguminosarum is correlated with its production of low molecular weight external polysaccharides (EPS). High-molecular-weight EPS increase water retention around the bacteria cell wall thus protecting against low external osmotic potential [64], [65]. While decreased rhizobial motility and growth at low soil water potentials may decrease nodulation frequency [66], co-inoculation with $V$. paradoxus 5C-2 partially alleviated negative effects of drought on nodulation [22]. Taken together, these data suggest that $V$. paradoxus 5C-2 survives drought conditions, and recovers its motility when a favourable water regime is re-established, which may assist rhizosphere colonisation following inoculation of plants grown in drying soil. 


\section{Plant influences on the microbial community}

Rhizosphere microbial activity can influence plant nutrient status while, vice versa, plants can also influence the physiology of microbial communities with their root exudates [67]. Root exudates vary from one species to another and are affected by plant age and nutrient status [68]. Plants may invest more than the $20 \%$ of the total carbon fixed in photosynthesis in rhizosphere carbon efflux [40]. This can benefit the plant if root exudate composition 'selects' beneficial microorganisms that colonize the roots. Soil porosity will affect the amount and distance which root exudates can travel [48], in turn affecting the chemo-attraction of the rhizobacteria. Since bacterial response time, or detection limit for root exudates, may alter bacterial fitness, bacteria utilize chemotaxis to assess a cocktail of exudates.

Root exudation varies along the root surface, determined by different root cell characteristics, thus affecting rhizospheric chemical composition from tip to base [69]. Moving away from the root tip defines different zones such as the root tip, with the root cap and the meristem, the elongation zone without any cell division, the maturation zone with differentiated xylem vessels and root hairs and finally the mature zone with dead root hairs (Figure 4C). For

maize, root surface $\mathrm{pH}$ changed along the root axis. Root tip $\mathrm{pH}$ was 7.6 and decreased linearly within the first $4 \mathrm{~mm}$ distance by 0.75 units and then increased linearly by $0.50 \mathrm{pH}$ units [70]. This is consistent with the release of organic anions, which will attract different microorganisms. Pseudomonas species preferentially colonise the root tip and the elongation zone of wheat [71]. Rhizobium leguminosarum and the fungal pathogen Nectria haematococca are attracted to the maturation zone of pea roots [72] while Bacillus sp. preferentially colonize the Arabidopsis root elongation zone [73]. Confocal microscopy is often used to determine the location of fluorescently labelled bacteria on the roots of plants grown in artificial media in vitro [71]. Alternatively, the numbers and distribution pattern of $V$. paradoxus $5 \mathrm{C}-2$ along the roots of both pea (Pisum sativum cv. Progress No. 9) and corn (Zea mays cv. ZB677) was measured, since inoculation increased growth of both species $[22,74]$. Colonization of pea roots was minimal near the tip and maximal near the base of the root where root hairs were present (Figure 4A, C). In contrast, colonization of corn roots showed no specific spatial distribution and was 10 -fold lower than in peas (Figure 4B). Differences in the relative concentrations of organic components 
such as amino acids and sugars exuded from corn and pea roots [75] were correlated with bacterial attraction to the roots of each species.

\section{$V$. paradoxus $5 \mathrm{C}-2$ dispersal in a soil mesocosm}

Like other bacteria, $V$. paradoxus can form biofilms on the plant root [76]. Bacterial dispersal occurs when they detach from the biofilm, switching to a planktonic lifestyle allowing new plant roots to be colonised. The dispersal process is complex and can be regulated by nutrient status and QS signals. It involves several steps such as the up-regulation of flagellar and chemotactic proteins and down-regulation of EPS [77]. Thus bacterial dispersal was tested in a mesocosm with field soil to determine bacterial movement in the rhizosphere and bulk soil.

When peas were grown in the mesocosm (Figure 5), V. paradoxus 5C-2 moved gradually away from the initial zone of inoculation, such that after 30 days, it was recovered from pea roots over $50 \mathrm{~cm}$ distant from the initial site of inoculation (Figure 5A). However, in the absence of plants, it moved only 30\% of this distance and no change in movement was detected from 12 days after inoculation (Figure 5B). Since $V$. paradoxus 5C-2 has a high dispersal capacity by moving between pea roots, field experiments were designed with substantial buffer strips between inoculated and uninoculated plots to prevent contamination. In other systems, runoff from sloping soil may risk cross-contamination of uninoculated plots [36] and should be considered in field trial design.

\section{Field application of a PGPR inoculum}

Having understood the physiological requirements of $V$. paradoxus 5C-2, a field experiment was designed to determine the effects of $V$. paradoxus $5 \mathrm{C}-2$ on pea (Pisum sativum) growth and development under soil drying conditions. It was performed in a field situated at $53^{\circ} 50^{\prime} 44.42^{\prime \prime} \mathrm{N}$ and $2^{\circ} 46^{\prime} 23.55^{\prime \prime} \mathrm{W}$ (Lee Farm, Bilsborrow, Lancashire, UK). The mineral content of this soil at this site was predominantly sandy (93\%), while silt and clay were $2.8 \%$ and $4.2 \%$ respectively. The organic matter content of the soil was $7.7 \%$ with a $\mathrm{pH}$ of 5.8 (water extraction). The field site $(13 \mathrm{~m} \times 7 \mathrm{~m})$ was covered by a semi-transparent plastic roof ("poly-tunnel") to exclude rainfall and the irrigation system installed. Soil moisture was monitored by an irrigation controller and data logger (Model GP1, Delta-T Devices, Burwell, UK) connected to soil 
moisture sensors (Delta-T Devices, Burwell, UK, SM-200 sensors). Half of the 24 plots were randomly assigned for $V$. paradoxus 5C-2 inoculation. During this field experiment, soil temperature at $5 \mathrm{~cm}$ depth varied between $15^{\circ} \mathrm{C}$ (week 1,01/09/2009) and $19^{\circ} \mathrm{C}$ (week 5 , 06/10/2009), while soil $\mathrm{pH}$ and water availability matched those optimal for $V$. paradoxus 5C-2 (Figure 3) [48].

Pea (Pisum sativum 'Progress No. 9') plants were germinated in seedling trays filled with an organic substrate (Levington's M3, Levington, UK) in a greenhouse at the Lancaster Environment Centre. The inoculation was done on the day of transplanting by submerging the peat blocks containing one seedling per block) in a bacterial solution ( 1 litre, $\left.10^{10} \mathrm{CFU} . \mathrm{ml}^{-1}\right)$. At the field site, seedlings were transplanted on 01/09/2009 and well watered initially, then water was withheld (reaching soil water potential of $-0.06 \mathrm{MPa}$ at $20 \mathrm{~cm}$ depth) from half the plants 3 days after transplanting. Shoot fresh weight was determined 21 and 47 days after transplanting. Roots were also sampled at these times to determine $V$. paradoxus 5C-2 colonizing the rhizosphere, using selective agar growth medium containing the antibiotics rifampicin, kanamycin and streptomycin to which this strain is resistant [22]. Colonies that resembled authentic $V$. paradoxus 5C-2 colonies were counted, and samples were taken to spread again on selective medium containing ACC as a sole nitrogen source for confirmation that bacteria contained $a c d S$.

While uninoculated plants were not colonized (since the plot arrangement reflected the results of Figure 5), $V$. paradoxus 5C-2 root colonization decreased 20-fold by the end of the experiment (Figure 6C). Nevertheless, well-watered plants inoculated with $V$. paradoxus 5C-2 had 50\% more nodules than uninoculated controls (Figure 6B). Drying soil decreased nodule number by $30 \%$, but the addition of $V$. paradoxus $5 \mathrm{C}-2$ restored nodule number to a level that exceeded control plants grown in well-watered conditions. $V$. paradoxus 5C-2 inoculation increased shoot biomass by $23 \%$ in well-watered soil (Figure 6A). Dryer soil significantly decreased shoot biomass of uninoculated controls by $22 \%$, but applying $V$. paradoxus $5 \mathrm{C}-2$ increased biomass above that of the well-watered controls. Thus in the field experiment $V$. paradoxus 5C-2 colonization in the roots was not adversely affected by drought, while drought decreased the number of nodules by $40 \%$ (Figure $6 \mathrm{~B}$ ). These results were qualitatively similar to 
those obtained in greenhouse experiments [22], even though soil type (and thus likely indigenous bacterial community) was very different.

Considering the expense of developing microbial inoculants, an important question is whether they can successfully colonize, and promote growth of, multiple plant species. Using the technique described above, multiple studies have measured $V$. paradoxus 5C-2 colonisation of the root system in a range of substrates, with levels of root colonisation similar in pea and other species, and between plants that were grown in well-watered versus drying soil. Thus $V$. paradoxus 5C-2 is competitive in the rhizosphere of a range of species, and promoted growth of plants grown in vitro, pot trials and field trials [78]. In further field experiments, V. paradoxus 5C-2 promoted potato, Solanum tuberosum, shoot growth and tuber yield [79]. Nevertheless, it can show specificity in its interaction and growth promotion according to the host genotype [80]. Of 4 tomato (Solanum lycopersicum) recombinant inbred lines tested for their growth and physiological responses to drought, only one was more drought resistant following $V$. paradoxus 5C-2 inoculation. While there is abundant evidence that this specific bacterial strain is a promising inoculant to boost growth of plants grown in drying soils, it is of interest to know if other $V$. paradoxus strains could have the same effect. $V$. paradoxus is a widespread bacterium across different soils and environments [43] and generally promotes plant growth under stress conditions such as drought [22], salinity [81], heavy metals [43] and phytopathogens [82]. Isolation of local strains, their enrichment and inoculation is theoretically possible. However, each strain has different properties and thus effectiveness. For example, 10 different strains of $V$. paradoxus were isolated, in which ACC deaminase activity in vitro varied by an order of magnitude [43]. Interestingly, in vitro root growth promotion also differed by circa $25 \%$. Thus not all the strains share the same effectiveness, and in the case of $V$. paradoxus, there will be differences in plant host specificity, that affect the capacity to integrate into the holobiome.

Bacterial mechanisms to cope with hyperosmotic stress comprise complex genetic regulation involving a large set of genes arranged in operons [83]. The $V$. paradoxus core genome possesses genes that configure the bacteria for coping with hyper-osmotic stress (Table 2), with two main mechanisms identified. First, osmotic adjustment allows the accumulation of physiologically compatible organic osmolytes utilising betaine-aldehyde dehydrogenase, and 
choline/betaine ABC transporters. Secondly, selective influx of inorganic ions such as potassium and chlorine occurs via trans-membrane channels. These genetic traits allow $V$. paradoxus to survive in the rhizosphere of extreme environments such as desert grasses [84], even if the soil matric potential in this niche has not been directly measured. While conserved genetic material across multiple strains suggests that $V$. paradoxus is well-adapted to proliferate in drying soil, it is less clear whether all strains can promote growth of plants in drying soil.

\section{Final remarks and future outlook}

One concern of introducing a new organism to the field is that it may alter microbial community structure: displacing some organisms and/or favouring the activity of plant pathogens [85]. However, this risk is likely minimal since bacterial colonization of the root systems decreased with time following inoculation (Figure 6C) [85]. While the rhizosphere is a very complex chemically interconnected niche, with plant-microbe and microbe-microbe communication forming trophic networks, the plant holobiome is dynamic and reacts following any disturbance [86]. Soil inoculation with PGPR sometimes facilitates their integration within soil trophic networks [22]. On the other hand, microbial stress tolerance traits are of pivotal importance for PGPR success under abiotic stress conditions and such information can help design field applications to mitigate drought-induced crop losses. This model of bacterial ecophysiology (Figure 7) and targeted experimentation in gradually more complex systems (Figures 3-5) leading to controlled field trials (Figure 6) provides a roadmap to lessen the probability of inoculum failure in the field.

PGPRs often possess more than one beneficial characteristic and complete genomic information can identify multiple potential growth-promoting mechanisms of each isolate [38]. Moreover, putative PGPRs can be identified by their specific genes rather than conventional bioassays. Information on the species dwelling in the plant holobiont (metagenomics) can help understand rhizosphere microbial community dynamics of a specific crop. Studying these effects in agroecosystems could help to deliver inocula that change bacterial dynamics towards the restoration of a microbial community promoting plant drought tolerance. In addition, with metatranscriptomics, it is possible to foresee the active bacteria or target genes and determine synergistic behaviours of the inoculum with native microbial population. Integrating the working 
model (Figure 7) with improved understanding of the microbial ecology of droughted agroecosystems may increase the reliability of microbial inocula, thereby enhancing grower acceptance.

\section{Acknowledgments}

We thank the Agriculture and Horticulture Development Board (AHDB) of England for funding a PhD studentship (Contract CP54) to RGT, Dr David Elphinstone of Myerscough College for assistance in conducting the field trial, and The Royal Society, Department of Environment, Food and Rural Affairs (DEFRA) of the UK government (Project WU0121) and the European Union (ROOTOPOWER project: Contract No. 289365) for funding rhizobacterial research at Lancaster University.

Author contributions: RGT designed experiments, wrote and edited the manuscript, AAB edited the manuscript and ICD designed experiments, wrote and edited the manuscript.

\section{References}

1. Felfelani F, Wada Y, Longuevergne L, Pokhrel YN. Natural and human-induced terrestrial water storage change: A global analysis using hydrological models and GRACE. J Hydrol 2017;553:105-18. https://doi.org/10.1016/j.jhydrol.2017.07.048.

2. Gordon LJ, Peterson GD, Bennett EM. (2008) Agricultural modifications of hydrological flows create ecological surprises. Trends Ecol Evolution 23: 211-9. https://doi.org/10.1016/j.tree.2007.11.011

3. Rodell M, Famiglietti JS, Wiese DN, Reager JT, Beaudoing HK, Landerer FW, et al. (2018) Emerging trends in global freshwater availability. Nature 557: 651-9. https://doi.org/10.1038/s41586-018-0123-1

4. Davies WJ, Zhang J, Yang J, Dodd IC. (2011) Novel crop science to improve yield and resource use efficiency in water-limited agriculture. J Agric Sci 149: 123-31. https://doi.org/10.1017/S0021859610001115

5. Inghelbrecht L, Goeminne G, Van Huylenbroeck G, Dessein J. (2017) When technology is more than instrumental: How ethical concerns in EU agriculture co-evolve with the development of GM crops. Agric Hum Values 34: 543. http://dx.doi.org/10.1007/s10460016-9742-z 
6. Fleury D, Jefferies S, Kuchel H, Langridge P. (2010) Genetic and genomic tools to improve drought tolerance in wheat. J Exp Bot 61: 3211-22. https://doi.org/10.1093/jxb/erq152

7. Rabbani MA, Maruyama K, Abe H, Khan MA, Katsura K, Ito Y, et al. (2003) Monitoring expression profiles of rice genes under cold, drought, and high-salinity stresses and abscisic acid application using cDNA microarray and RNA Gel-Blot analyses. Plant Physiol 133: 1755-67. https://doi.org/10.1104/pp.103.025742

8. Tardieu F, Simonneau T, Muller B (2018) The physiological basis of drought tolerance in crop plants: a scenario-dependent probabilistic approach. Ann Rev Plant Biol 69: 733-59. https://doi.org/10.1146/annurev-arplant-042817-040218

9. Ngumbi E, Kloepper. (2016) Bacterial-mediated drought tolerance: Current and future prospects. Applied Soil Ecol 105: 109-25. https://doi.org/ 10.1016/j.apsoil.2016.04.009

10. Etesami H, Maheshwari DK. (2018) Use of plant growth promoting rhizobacteria (PGPRs) with multiple plant growth promoting traits in stress agriculture: Action mechanisms and future prospects. Ecotoxicol Env Safety 156: 225-46. https://doi.org/10.1016/j.ecoenv.2018.03.013

11. Glick BR (2014) Bacteria with ACC deaminase can promote plant growth and help to feed the world. Microbiol Res 169: 30-39. https://doi.org/10.1016/j.micres.2013.09.009

12. Dodd IC. (2005) Root-to-shoot signalling: Assessing the roles of 'up' in the up and down world of long-distance signalling in planta. Plant Soil 274: 251-70. https://www.jstor.org/stable/24129047

13. Dodd IC, Egea G, Watts CW, Whalley WR. (2010a) Root water potential integrates discrete soil physical properties to influence ABA signalling during partial rootzone drying. J Exp Bot 61: 3543-51. 10.1093/jxb/erq195

14. Dubois M, Van den Broeck L, Inzé D. (2018) The Pivotal Role of Ethylene in Plant Growth. Trends Plant Sci 23: 311-23. https://doi.org/10.1016/j.tplants.2018.01.003

15. Morgan PW, Drew MC. (1997) Ethylene and plant responses to stress. Physiol Plant 100: 620-30. https://doi.org/10.1111/j.1399-3054.1997.tb03068.x

16. Czarny JC, Grichko VP, Glick BR. (2006) Genetic modulation of ethylene biosynthesis and signaling in plants. Biotech Advances 24: 410-9. DOI:10.1016/j.biotechadv.2006.01.003

17. Masucci JD, Schiefelbein JW. 1996. Hormones act downstream of TTG and GL2 to promote root hair outgrowth during epidermis development in the Arabidopsis root. Plant Cell 8: 1505 - 1517. DOI: https://doi.org/10.1105/tpc.8.9.1505 
18. Iqbal N, Khan NA, Ferrante A, Trivellini A, Francini A, Khan MIR. (2017) Ethylene role in plant growth, development and senescence: interaction with other phytohormones. Front. Plant Sci. 8:475. doi: 10.3389/fpls.2017.00475.

19. McDonnell L, Plett JM, Andersson-Gunneras S, Kozela C, Dugardeyn J, Van Der Straeten D, et al. (2009) Ethylene levels are regulated by a plant encoded 1-aminocyclopropane-1carboxylic acid deaminase. Physiol. Plant. 136: 94-109. doi: 10.1111/j.13993054.2009.01208.x

20. Van de Poel B, Van Der Straeten D. (2014) 1-aminocyclopropane-1-carboxylic acid (ACC) in plants: more than just the precursor of ethylene ! Frontiers Plant Sci 5: 640. https://doi.org/10.3389/fpls.2014.00640

21. Chen L, Dodd IC, Theobald JC, Belimov AA, Davies WJ. (2013) The rhizobacterium Variovorax paradoxus 5C-2, containing ACC deaminase, promotes growth and development of Arabidopsis thaliana via an ethylene-dependent pathway. J Exp Bot 64: 1565-73. https://doi.org/10.1093/jxb/ert031

22. Belimov AA, Dodd IC, Hontzeas N, Theobald JC, Safronova VI, Davies WJ (2009) Rhizosphere bacteria containing 1-aminocyclopropane-1-carboxylate deaminase increase yield of plants grown in drying soil via both local and systemic hormone signalling. New Phytol 181: 413-23. DOI: 10.1111/j.1469-8137.2008.02657.x

23. Timmusk S, Paalme V, Pavlicek T, Bergquist J, Vangala A, Danilas T, et al. (2011) Bacterial distribution in the rhizosphere of wild barley under contrasting microclimates. PLOS One 6:e17968. doi: 10.1371/journal.pone.0017968

24. Stromberger ME, Abduelafez I, Byrne P, Canela MM, Asma A. Elamari DK. et al. (2017) Genotype-specific enrichment of 1 aminocyclopropane-1-carboxylic acid deaminasepositive bacteria in winter wheat rhizospheres. Soil Sci Soc America J 81: 796-805. DOI:10.2136/sssaj2016.12.0437

25. French KE, Tkacz A, Turnbull LA. (2017) Conversion of grassland to arable decreases microbial diversity and alters community composition. Applied Soil Ecol 110: 43-52. doi: 10.1016/j.apsoil.2016.10.015

26. Wu X-H, Zhang Y, Du, P-Q, Xu J, Dong F-S, Liu, X.-G. et al. (2018) Impact of fomesafen on the soil microbial communities in soybean fields in Northeastern China. Ecotoxicol Env Safety 148, 169-76. doi: 10.1016/j.ecoenv.2017.10.003

27. Hartmann A., Rothballer M., and M. Schmid. Lorenz Hiltner, a pioneer in rhizosphere microbial ecology and soil bacteriology research. Plant Soil 312:7-14 (2008). DOI: 


\section{$10.1007 / \mathrm{s} 11104-007-9514-\mathrm{Z}$}

28. Berg G, Grube M, Schloter M, Smalla K (2014) Unraveling the plant microbiome: looking back and future perspectives. Front Microbiol 5:148. doi: 10.3389/fmicb.2014.00148

29. Bouffaud M.-L., Renoud S, Dubost A, Moënne-Loccoz Y, Muller D. (2018) 1aminocyclopropane-1-carboxylate deaminase producers associated to maize and other Poaceae species. Microbiome 6:114. doi:10.1186/s40168-018-0503-7

30. Hassani MA, Durán P, Hacquard S. (2018) Microbial interactions within the plant holobiont. Microbiome 6: 58. doi: 10.1186/s40168-018-0445-0

31. Rosenberg E, Zilber-Rosenberg I (2018) The hologenome concept of evolution after 10 years. Microbiome 6:78. doi:10.1186/s40168-018-0457-9

32. Dong L, Xu J, Zhang L, Yang J, Liao B, Li X, Chen S (2017) High-throughput sequencing technology reveals that continuous cropping of American ginseng results in changes in the microbial community in arable soil. Chinese Medicine 12: 18. DOI: 10.1186/s13020-0170139-8

33. Naylor D, De Graaf S, Purdom E, Coleman-Derr D. (2017) Drought and host selection influence bacterial community dynamics in the grass root microbiome. ISME Journal 11, 2691. DOI: $10.1038 /$ ismej.2017.118

34. de Vries FT, Griffiths RI, Bailey M, Craig H, Girlanda M, Gweon HS, et al. (2018) Soil bacterial networks are less stable under drought than fungal networks. Nature Communications 9: 3033. https://doi.org/10.1038/s41467-018-05516-7

35. Piromyou P, Buranabanyat B, Tantasawat P, Tittabutr P, Boonkerd N, Teaumroong N. (2011) Effect of plant growth promoting rhizobacteria (PGPR) inoculation on microbial community structure in rhizosphere of forage corn cultivated in Thailand. Eur J Soil Biol 47: 44-54. DOI: 10.1016/j.ejsobi.2010.11.004

36. Tabassum B, Khan A, Tariq M, Ramzan M, Iqbal Khan MS, Shahid N, et al. (2017) Bottlenecks in commercialisation and future prospects of PGPR. Applied Soil Ecol 121: 102-117. doi: 10.1016/j.apsoil.2017.09.030

37. Dutta S, Podile AR. (2010) Plant Growth Promoting Rhizobacteria (PGPR): the bugs to debug the root zone. Critical Rev Microbiol 36: 232-44. DOI:10.3109/10408411003766806

38. Trabelsi D, Mhamdi R. (2013) Microbial inoculants and their impact on soil microbial communities: a review. BioMed Research International 11: 863240. http://dx.doi.org/10.1155/2013/863240 
39. Lauber CL, Hamady M, Knight R, Fierer N. (2009) Pyrosequencing-based assessment of soil ph as a predictor of soil bacterial community structure at the continental scale. Applied Env Microbiol 75: 5111-20. doi: 10.1128/AEM.00335-09.

40. Fierer N (2017) Embracing the unknown: disentangling the complexities of the soil microbiome. Nature Reviews Microbiol 15: 579-90. doi: 10.1038/nrmicro.2017.87.

41. Satola B, Wübbeler JH, Steinbüchel A. (2013) Metabolic characteristics of the species Variovorax paradoxus. Applied Microbiol Biotech 97, 541-60. doi: 10.1007/s00253-0124585-Z

42. Han J-I, Choi H-K, Lee S-W, Orwin PM, Kim J, LaRoe SL, et al. (2011) Complete genome sequence of the metabolically versatile plant growth-promoting endophyte Variovorax paradoxus S110. J Bacteriol 193: 1183-1190. 10.1128/JB.00925-10

43. Belimov AA, Hontzeas N, Safronova VI, Demchinskaya SV, Piluzza G, Bullitta S, et al. (2005) Cadmium-tolerant plant growth-promoting bacteria associated with the roots of Indian mustard (Brassica juncea L. Czern.). Soil Biol Biochem 37: 241-50. doi:10.1016/j.soilbio.2004.07.033

44. Tettelin HD, Riley C, Cattuto C, Medini D. (2008) Comparative genomics: the bacterial pan-genome. Current Opinion Microbiol 11: 472-7. DOI: 10.1016/j.mib.2008.09.006

45. Chaudhari NM, Gupta VK, Dutta C. (2016) Bpga-An ultra-fast pan-genome analysis pipeline. Sci Reports 6: 24373. https://doi.org/10.1038/srep24373

46. Rangasamy K, Athiappan M, Devarajan N, Samykannu G, Parray JA, Aruljothi KN, et al. (2018) Pesticide degrading natural multidrug resistance bacterial flora. Microbial Pathogenesis 114: 304-10. doi: 10.1016/j.micpath.2017.12.013

47. Jiang F, Chen L, Belimov AA, Shaposhnikov A, Gong F, Meng X, et al. Multiple impacts of the plant growth-promoting rhizobacterium Variovorax paradoxus $5 \mathrm{C}-2$ on nutrient and ABA relations of Pisum sativum. J Exp Bot 63: 6421-30. doi: 10.1093/jxb/ers301.

48. Whitman T, Neurath R, Perera A, Chu-Jacoby I, Ning D, Zhou J, et al. (2018) Microbial community assembly differs across minerals in a rhizosphere microcosm. Env Microbiol 20:4444-60. doi: 10.1111/1462-2920.14366

49. Santana MM, Gonzalez JM. (2015) High temperature microbial activity in upper soil layers. FEMS Microbiol Letters 362: UNSP fnv182. doi: 10.1093/femsle/fnv182

50. Sheik CS, Beasley WH, Elshahed MS, Zhou X, Luo Y, Krumholz LR. (2011) Effect of warming and drought on grassland microbial communities. ISME Journal 5: 1692-1700. doi: 
10.1038/ismej.2011.32.

51. Kang S, Kim S, Oh S, Lee D. (2000) Predicting spatial and temporal patterns of soil temperature based on topography, surface cover and air temperature. Forest Ecol Management 136: 173-84 DOI: 10.1016/S0378-1127(99)00290-X

52. Stres B, Danevčič T, Pal L, Fuka MM, Resman L, Leskovec S, et al. (2008) Influence of temperature and soil water content on bacterial, archaeal and denitrifying microbial communities in drained fen grassland soil microcosms. FEMS Microbiol Ecology 66: 11022. doi: 10.1111/j.1574-6941.2008.00555.x

53. Dodds GT, Madramootoo CA, Janik D, Fava E, Stewart KA. (2003) Factors affecting soil temperature under plastic mulches. Tropical Agriculture 80: 6-13

54. Soussi A, Ferjani R, Marasco R, Guesmi A, Cherif H, Rolli E, et al. (2016) Plant-associated microbiomes in arid lands: diversity, ecology and biotechnological potential. Plant Soil 405: 357-70. https://doi.org/10.1007/s11104-015-2650-y.

55. Malik AA, Puissant J, Buckeridge KM, Goodall T, Jehmlich N, Chowdhury S, et al. (2018) Land use driven change in soil $\mathrm{pH}$ affects microbial carbon cycling processes. Nature Comms 9: 3591. DOI: 10.1038/s41467-018-05980-1

56. Maurer LM, Yohannes E, Bondurant SS, Radmacher M, Slonczewski JL. (2005) pH Regulates genes for flagellar motility, catabolism, and oxidative stress in Escherichia coli K-12. J Bacteriol 187: 304-19. DOI:10.1128/JB.187.1.304-319.2005

57. Tasaki S, Nakayama M, Shoji W (2017) Self-organization of bacterial communities against Environmental $\mathrm{pH}$ variation: Controlled chemotactic motility arranges cell population structures in biofilms. PLOS One 12: e0173195. doi: 10.1371/journal.pone.0173195

58. Saikia J, Sarma RK, Dhandia R, Yadav A, Bharali R, Gupta VK, Saikia R. (2018) Alleviation of drought stress in pulse crops with ACC deaminase producing rhizobacteria isolated from acidic soil of Northeast India. Sci Reports 8:356. | DOI:10.1038/s41598-01821921-w

59. Zerrouk IZ, Benchabane M, Khelifi L, Yokawa K, Ludwig-Muller J, Baluska F. (2016) A Pseudomonas strain isolated from date-palm rhizospheres improves root growth and promotes root formation in maize exposed to salt and aluminum stress. J Plant Physiol 191, 111-9. doi: 10.1016/j.jplph.2015.12.009.

60. Cytryn EJ, Sangurdekar DP, Streeter JG, Franck WL, Chang WS, Stacey G, et al. (2007) Transcriptional and physiological responses of Bradyrhizobium japonicum to desiccationinduced stress. J Bacteriol 189: 6751-62. DOI: 10.1128/JB.00533-07 
61. Chowdhury N, Marschner P, Burns RG. (2011) Soil microbial activity and community composition: Impact of changes in matric and osmotic potential. Soil Biol Biochem 43: 1229-36

62. Whalley WR, Ober ES, Jenkins M (2013) Measurement of the matric potential of soil water in the rhizosphere. J Exp Bot 64: 3951-63. doi: 10.1093/jxb/ert044.

63. Potts M, Slaughter SM, Hunneke FU, Garst J, Helm RF (2005) Desiccation Tolerance of Prokaryotes: Application of Principles to Human Cells. Integrative and Comparative Biology 45: 800-809, https://doi.org/10.1093/icb/45.5.800

64. Dechesne A, Wang G, Gülez G, Or D, Smets BF. (2010) Hydration-controlled bacterial motility and dispersal on surfaces. Proc Nat Acad Sci USA 107: 14369-72. doi: $10.1073 /$ pnas. 1008392107

65. Wang H, Jiang X, Mu H, Liang X, Guan H. (2007) Structure and protective effect of exopolysaccharide from P-agglomerans strain KFS-9 against UV radiation. Microbiol Res 162: 124-9. DOI:10.1016/j.micres.2006.01.011

66. Rachwał K, Matczyńska E, Janczarek M. (2015) Transcriptome profiling of a Rhizobium leguminosarum bv. trifolii rosR mutant reveals the role of the transcriptional regulator RosR in motility, synthesis of cell-surface components, and other cellular processes. BMC Genomics 16: 1111. doi:10.1186/s12864-015-2332-4

67. Leff JW, Bardgett RD, Wilkinson A, Jackson BG, Pritchard WJ, De Long JR, et al. (2018) Predicting the structure of soil communities from plant community taxonomy, phylogeny, and traits. ISME Journal 12: 1794-1805. doi: 10.1038/s41396-018-0089-x

68. Sauer D, Kuzyakov Y, Stahr K. (2006) Spatial distribution of root exudates of five plant species as assessed by $14 \mathrm{C}$ labeling. J Plant Nutrition Soil Sci 169: 360-2. DOI:10.1002/jpln.200621974

69. Walker TS, Bais HP, Grotewold E, Vivanco JM. (2003) Root exudation and rhizosphere biology. Plant Physiol 132: 44-51. DOI: 10.1104/pp.102.019661

70. Peters WS, Felle HH. (1999) The correlation of profiles of surface $\mathrm{pH}$ and elongation growth in maize roots. Plant Physiol 121: 905-12. doi: 10.1104/pp.121.3.905

71. Watt M, Hugenholtz P, White R, Vinall K. (2006) Numbers and locations of native bacteria on field-grown wheat roots quantified by fluorescence in situ hybridization (FISH). Env Microbiol 8: 871-84. DOI: 10.1111/j.1462-2920.2005.00973.x

72. Gunawardena U, Rodriguez M, Straney D, Romeo JT, Van Etten HD, Hawes MC. (2005) 
Tissue-specific localization of pea root infection by Nectria haematococca. Mechanisms and Consequences. Plant Physiol 137: 1363-74. DOI: 10.1104/pp.104.056366

73. Rudrappa T, Czymmek KJ, Paré PW, Bais HP (2008) Root-secreted malic acid recruits beneficial soil bacteria. Plant Physiol 148: 1547-56. doi: 10.1104/pp.108.127613.

74. Dodd IC, Jiang F, Teijeiro RG, Belimov AA, Hartung W. (2009) The rhizosphere bacterium Variovorax paradoxus $5 \mathrm{C}-2$ containing ACC deaminase does not increase systemic ABA signaling in maize (Zea mays L.). Plant Signaling Behaviour 4, 519-21. doi: 10.4161/psb.4.6.8574

75. Phillips DA, Fox TC, King, MD, Bhuvaneswari TV, Teuber LR (2004) Microbial products trigger amino acid exudation from plant roots. Plant Physiol 136: 2887-94. DOI:10.1104/pp.104.044222

76. Rudrappa T, Biedrzycki ML, Bais HP. (2008) Causes and consequences of plant-associated biofilms. FEMS Microbiol Ecol 64: 153-66. doi: 10.1111/j.1574-6941.2008.00465.x

77. Guilhen C, Forestier C, Balestrino D. (2017) Biofilm dispersal: multiple elaborate strategies for dissemination of bacteria with unique properties. Mol Microbiol 105: 188-210. doi: 10.1111/mmi.13698

78. Dodd IC, Belimov AA, Elphinstone ED, Chen L, Teijeiro RG, Kemp C, Fielding HA, Wright HR. (2013) Exploiting rhizobacteria that mediate plant hormone status. Aspects Applied Biol 120, 29-34

79. Belimov AA, Dodd IC, Safronova VI, Shaposhnikov AI, Azarova TS, Makarova NM, et. al. (2015) Rhizobacteria that produce auxins and contain 1-amino-cyclopropane-1-carboxylic acid deaminase decrease amino acid concentrations in the rhizosphere and improve growth and yield of well-watered and water-limited potato (Solanum tuberosum). Ann Applied Biol 167: 11-25. https://doi.org/10.1111/aab.12203

80. Calvo-Polanco M, Sánchez-Romera B, Aroca R; Asins MJ, Declerck S, Dodd IC et al. (2016) Exploring the use of recombinant inbred lines in combination with beneficial microbial inoculants (AM fungus and PGPR) to improve drought stress tolerance in tomato. Env Exp Bot, 131: 47-57. https://doi.org/10.1016/j.envexpbot.2016.06.015

81. Nadeem SM, Ahmad M, Naveed M, Imran M, Zahir ZA, Crowley DE. (2016) Relationship between in vitro characterization and comparative efficacy of plant growth-promoting rhizobacteria for improving cucumber salt tolerance. Archives of Microbiology 198: 379387 doi:10.1007/s00203-016-1197-5. doi: 10.1007/s00203-016-1197-5.

82. Uroz S. (2003). Novel bacteria degrading N-acylhomoserine lactones and their use as 
quenchers of quorum-sensing-regulated functions of plant-pathogenic bacteria. Microbiology 149: 1981-1989. doi:10.1099/mic.0.26375-0. doi: $10.3389 /$ fmicb.2019.00455

83. Osbourn, Anne E, and Ben Field. "Operons." Cellular and molecular life sciences : CMLS vol. 66,23 (2009): 3755-75. doi:10.1007/s00018-009-0114-3

84. Castro-Sowinski S, Herschkovitz Y, Okon Y, Jurkevitch E (2007) Effects of inoculation with plant growth-promoting rhizobacteria on resident rhizosphere microorganisms. FEMS Microbiol Letters 276: 1-11. DOI: 10.1111/j.1574-6968.2007.00878.x

85. Bender SF, Wagg C, van der Heijden MGA (2016) An underground revolution: biodiversity and soil ecological engineering for agricultural sustainability. Trends Ecol Evolution 31: 440-52. doi: 10.1016/j.tree.2016.02.016.

86. Smith CR, Blair PL, Boyd C, Cody B, Hazel A, Hedrick A, et al. (2016) Microbial community responses to soil tillage and crop rotation in a corn/soybean agroecosystem. Ecol Evolution 6: 8075-84. doi: 10.1002/ece3.2553

\section{Figure and Table legends}

Figure 1. Ethylene biosynthesis. Methionine is converted by (1) S-adenosylmethionine synthetase (SAM synthetase) to S-adenosyl methionine (SAM). Next, SAM is converted to 1Aminocyclopropane-1-carboxylate (ACC) and 5'-methylthioadenosine (MTA) by (2) 1aminocyclopropane-1-carboxylate synthase (ACS). MTA can enter in the Yang cycle that refills the pool of 1-methionine. (3) 1-aminocyclopropane-1-carboxylate oxidase (ACO) turns ACC into ethylene, $\mathrm{HCN}$ and $\mathrm{CO}_{2}$. Alternatively, (4) ACC deaminase deaminates ACC resulting in 2oxobutanoate and ammonia. (5) $\gamma$-glutamyl-transpeptidase (GGT) forms $\gamma$-glutamyl-ACC (GACC) by addition of a glutamyl group (6) ACC-N-malonyl transferase (AMT) forms 1malonyl-ACC (MACC) from malonyl-CoA and ACC while (7) an enzyme encoded by Jasmonic acid resistance 1 (JAR1) yields jasmonyl-ACC (JA-ACC).

Figure 2. Core and Strain-Specific Gene Extrapolation. A pan-genome study was implemented to determine the Variovorax paradoxus core genome, variable and unique genome. Seven strains of $V$. paradoxus (Table 1) were downloaded from NCBI Genome and their pan-genome analysis was accomplished with bacterial pan-genome analysis (BPGA) program [60]. Specific functions of the $V$. paradoxus pan-genome were delivered based on KEGG (Kyoto Encyclopedia of Genes and Genomes) biological pathways database.

Figure 3. Effects of temperature (A), $\mathrm{pH}$ (B) and osmotic potential (C) on V. paradoxus 5C-2 growth after 18 hours of incubation ( $)$ and motility after 72 hours (X). For (A) and (B) growth was assessed in TSB (liquid medium) while motility was tested in M8/M9 minimal medium solidified with $0.5 \%$ agarose. For (C) and (D), TSB (survival test) and semi-solid M8/M9 
(motility test) plates were amended with glycerol. (D) Resumption of $V$. paradoxus 5C-2 motility (on MS, $0.25 \%$ agar) after exposure (12 hours) to different osmotic potentials. Symbols are means \pm SE of 9 replicates.

Figure 4. V. paradoxus 5C-2 distribution along pea (A) and corn (B) roots. Root anatomy (C). Data are means $\pm \mathrm{SE}$ of 3 replicates.

Figure 5. V. paradoxus 5C-2 dispersal between the rhizosphere of pea plants (A) and in bulk soil without plants (B). Root colonisation by bacteria was assessed at fixed distances from the initial inoculation zone (yellow line), four times after inoculation. Symbols are means \pm SE of 3 replicates.

Figure 6. Shoot biomass (A), nodule number (B) and $V$. paradoxus 5C-2 root colonisation (C) of inoculated and uninoculated plants grown in well-watered and drying soil in a field experiment. Bars are means $\pm \mathrm{SE}$ of 6 plots. Different letters above the bars indicate significant treatment differences determined by LSD test $(p<0.05)$. (D) Field experiment design. Seedlings were transplanted to coloured plots while uncoloured plots were fallow. Plots were inoculated with $V$. paradoxus 5C-2 (red cells) or not (control - blue cells). The outer two beds (each comprising 6 pea plots) were watered throughout the experiment while water was withheld from the middle two (red arrows).

Figure 7. Roadmap for soil and PGPR monitoring, leading to inoculum application in field experiments, as outlined in this manuscript.

Table 1. Pan-genome characteristics of seven strains of Variovorax paradoxus

Table 2. Operons for hyperosmotic stress resistance find in the core genome of Variovorax paradoxus. The genes are represented in the genomic context of the reference strain EPS NC_014931.1 (directions coordinates). Information on putative operon were obtained through UniProtKB (https://www.uniprot.org). 